\title{
Hereditary Folate Malabsorption
}

National Cancer Institute

\section{Source}

National Cancer Institute. Hereditary Folate Malabsorption. NCI Thesaurus. Code C156424.

An autosomal recessive condition caused by mutation(s) in the SCL46A1 gene, encoding proton-coupled folate transporter. It is characterized by low concentrations of folate resulting in megaloblastic anemia, immune deficiency, and neurologic deficits. 